\title{
STUDYING THE THERMALLY POLLUTED MIXING ZONE SIZE IN OPEN CHANNELS
}

\author{
Omima, A. Kotob ${ }^{1}$, Samir A. S. Ibrahim ${ }^{1}$, and Hany, A. S. Kater ${ }^{2}$ \\ 1-Hydraulics Research Institute, National Water Research Centre, Egypt \\ 2-Department of Mechanical Power Engineering, Faculty of Engineering, \\ Cairo University, Egypt
}

\begin{abstract}
This work investigates experimentally the characteristics of the thermal area of pollution resulting from surface discharge outfalls of the steam electrical power plant cooling system. The experimental program was carried out in a rectangular flume inside the northern experimental hall of the Hydraulics Research Institute (HRI) in Egypt. The flume has dimensions of $17.8 \mathrm{~m}$ length, $2.5 \mathrm{~m}$ width, and $0.5 \mathrm{~m}$ deep. Formulae and curves to identify the mixing zone center-line length for different outfall angles were developed. The predicted formulae could be used in the cooling system surface discharge design phase to predict the minimum dilution of the thermal plume at different discharge rates in Egypt. The predicted formulae could also help in updating the environmental and water legislations in Egypt.

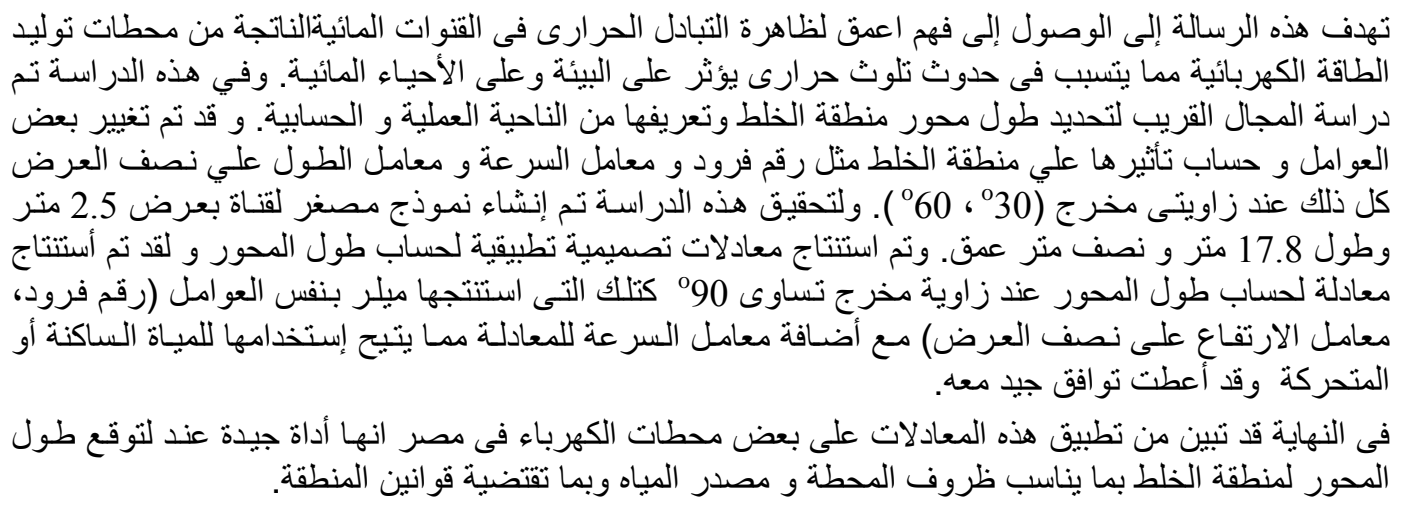

Keywords: Mixing zone center line, outfall angle, near field, thermal discharge, temperature, Densimetric Froude Number and aspect ratios

\section{INTRODUCTION}

Egypt has the highest population in the Arab World. Egypt had an installed electric generating capacity of 18.936 giga-watts in 2006/2007 with plans to raise the capacity to more than 23.0 giga-watts by year 2010. About $73 \%$ of Egypt's electric generating capacity is thermal and $15 \%$ hydroelectric mostly from Aswan High Dam.

The thermal power plants represent the main source of thermal pollution. This is due to the low thermal efficiencies of thermal power plants- typically (32$36 \%$ ). So, according to the second low of thermodynamics a large amount of heat is rejected. This waste heat is removed in the plant condensers through circulating once through cooling water system [1], which is often discharged to a nearby natural body of water such as rivers, lake, or coastal water. This heat increases the water temperature, the excess temperature decreases the dissolved oxygen inside the water and increases the respiration and the heart beat rate of fish thus decreasing the metabolism process and leading to the death of aquatic life. The excess temperature slows the metabolic reaction as it acts like an inhibitor. On the other hand, the rate of any chemical reaction is doubled by raising the temperature by $10{ }^{\circ} \mathrm{C}$ thus affecting the overall productivity of water species.

Discharging the hot water can be achieved either by surface or submerged discharge as shown in Fig. 1. This study is concerned with the deep water in surface discharge specially the near field region where the momentum force is dominant [2], the ambient water is said to be deep where the jet is free to mix due to entrainment and buoyancy and is not constrained by the bed. It can be noted that the deep water may be defined according to the following relation, [3]:

$$
\frac{h_{\max }}{H} \prec 0.75
$$


Where: $\mathrm{h}_{\max }=$ the maximum depth that the plume will reach if unhindered by the bottom and is equal $\operatorname{to}\left(0.42 F_{O} A_{s}^{\frac{1}{4}} \sqrt{h_{o} b_{o}}\right)$,

$\mathrm{H}=$ water depth in the river,

$F_{o}=$ Densimetric Froude Number,

$\mathrm{A}_{\mathrm{s}}=$ aspect ratio $h_{o} / b_{o}$,

$h_{\mathrm{o}}=$ outfall depth and $\mathrm{b}_{\mathrm{o}}=$ half width of outfall.

Fig. 2 Sketch shows some parameters used in the study.

From the above, it could be concluded that the most effective dimensionless variables are cross-flow ratio $\left(\mathrm{R}=\frac{U_{a}}{U_{o}}\right)$ where $\mathrm{U}_{\mathrm{o}}$ is the thermal discharge velocity,

$\mathrm{U}_{\mathrm{a}}$ is the ambient velocity, aspect ratio $\left(A_{s}=h_{o} / b_{o}\right)$ which is the ratio of the outfall water depth $\left(\mathrm{h}_{\mathrm{o}}\right)$ and half of the outfall width $\left(b_{0}\right)$, and $F_{o}$ is the Densimetric Froude Number

$$
F_{O}=\frac{u_{o}}{\sqrt{\frac{\Delta \rho}{\rho} g h_{o}}}
$$

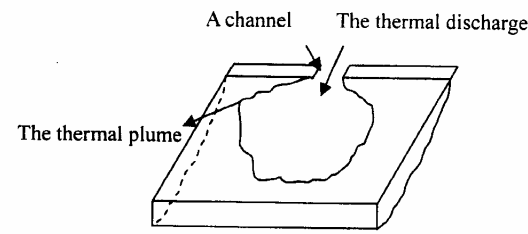

(a) Surface discharge

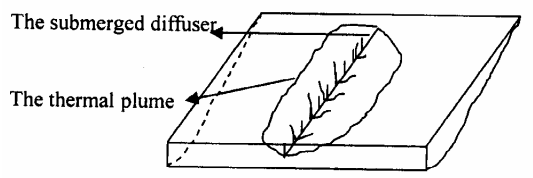

(b) Submerged discharge

Fig. 1 Ways of thermal discharges, Miller and Brighouse
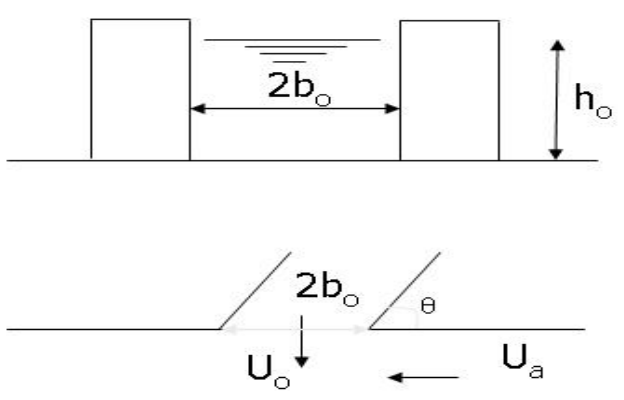

Fig. 2 Sketch shows some parameters used in the study

\section{DATA of SOME POWER PLANTS in EGYPT}

Thermal discharge, temperature, and aspect ratios of some power plants in Egypt are shown in Table (1). It is clear that the aspect ratios $\left(A_{s}\right)$ range between 0.15 and 2 . The temperature difference between the hot discharge temperature and ambient water temperature $\left(\Delta \mathrm{T}_{\mathrm{o}}\right)$ ranges between $8{ }^{\circ} \mathrm{C}$ and $10^{\circ} \mathrm{C}$. The discharge ratios $\left(\mathrm{Q}_{0} / \mathrm{Q}_{\mathrm{a}}\right)$ range between 0.09 and 0.839 .

In this study it is considered the ambient discharge of the winter closure period in Egypt, where the ambient velocity is the lowest. This is the critical case, where the thermal power plants discharge hot water at very low ambient velocities. The different factors of the experimental program were selected according to the data in Table (1), thermal discharge, temperature, and aspect ratios of some power plants in Egypt, Hydraulics Research Institute (HRI), [4] to [11].

Table 1 Data of some power plants in Egypt

\begin{tabular}{|c|c|c|c|c|c|c|}
\hline $\begin{array}{c}\text { Power } \\
\text { plant } \\
\text { name }\end{array}$ & $\begin{array}{c}\text { Angle } \\
\text { of } \\
\text { outfall }\end{array}$ & $\begin{array}{c}\text { Hot } \\
\text { disch. } \\
\mathrm{m}^{3} / \mathrm{s}\end{array}$ & $\begin{array}{c}\text { Ambient } \\
\text { disch. } \\
\mathrm{m}^{3} / \mathrm{s}\end{array}$ & $\begin{array}{c}\text { Disch. } \\
\text { Ratio }\end{array}$ & $\begin{array}{c}\text { Hot } \\
\text { disch. } \\
\text { temp. } \\
{ }^{\circ} \mathrm{C}\end{array}$ & $\begin{array}{c}\text { Aspect } \\
\text { ratio }\end{array}$ \\
\hline $\begin{array}{c}\text { Cairo } \\
\text { West }\end{array}$ & $60^{\circ}$ & 56.90 & 630 & 0.09 & 9.6 & 2 \\
\hline $\begin{array}{c}\text { Cairo } \\
\text { South }\end{array}$ & $60^{\circ}$ & 58.34 & 525 & 0.111 & 9.6 & 1.07 \\
\hline $\begin{array}{c}\text { El- } \\
\text { Kureimat }\end{array}$ & $60^{\circ}$ & 80.00 & 183 & 0.437 & 9.6 & 0.82 \\
\hline $\begin{array}{c}\text { Cairo } \\
\text { North }\end{array}$ & $60^{\circ}$ & 27.20 & 35 & 0.777 & 8 & 0.6 \\
\hline $\begin{array}{c}\text { New } \\
\text { Nubaria } \\
\text { Modules I } \\
\& \text { II }\end{array}$ & $60^{\circ}$ & 26.00 & 31 & 0.839 & 10 & 0.15 \\
\hline $\begin{array}{c}\text { New } \\
\text { Nubaria } \\
\text { Module } \\
\text { III }\end{array}$ & $30^{\circ}$ & 21.60 & 60 & 0.36 & 10 & 0.476 \\
\hline $\begin{array}{c}\text { Tebeen } \\
\text { module I }\end{array}$ & $60^{\circ}$ & 20.00 & 1147 & 0.017 & 9.3 & 0.3 \\
\hline $\begin{array}{c}\text { El- } \\
\text { module II }\end{array}$ & $30^{\circ}$ & 26.00 & 1147 & 0.022 & $8-10$ & 0.223 \\
\hline
\end{tabular}




\section{STUDY OBJECTIVE}

The majority of the studies of the thermal plume size were carried for the thermal discharge into shallow water. On the other hand deep water did not have the same intensity. So, the main objective of this study is to develop empirical formulae for surface discharge of different outfall orientation to predict the thermal plumes center-line length.

\section{EXPERIMENTAL PROCEDURE}

In order to accomplish the study objective, a flume with $17.8 \mathrm{~m}$ total length, $2.5 \mathrm{~m}$ width and $0.5 \mathrm{~m}$ depth was built in HRI. This was chosen with scale modeling satisfying Reynolds Number and Froude Number, to cover the boundary conditions and constrained with the facility of the place in HRI. The feeding system is shown in Fig. 3. In any test group, the experiments proceeded as follows:

1. The flume is divided into 30 cross-sections which are distributed at different distances that are marked and fixed for all runs as shown in Fig. 4.

2. Twenty five sensors are firstly calibrated and mounted on a bridge at equal distances $10 \mathrm{~cm}$ apart. The coordinates of the sensors are measured related to a fixed point.

3. To measure the temperature at different levels, the bridge is mounted on a holder which facilitate the up and down movement every $2 \mathrm{~cm}$.

Data analyzing proceeded as the following:

- The temperature difference $(\Delta \mathrm{T})=\left(\mathrm{T}_{\mathrm{i}}-\mathrm{T}_{\mathrm{c}}\right)$, was plotted in contours (isotherms) as in Fig. 4. Where $T_{i}$ is the water temperature measured by sensors and $T_{c}$ is the ambient water temperature in the well.

- The plotted contours for every case then were exported into Autocad program, where the center line lengths of different contours were measured as in Fig. 5.

- The data was arranged in excel sheets then entered to a data fit computer program to get the relations for thermal plume center line length.

- At last, verify these equations on study cases and draw charts for the measured data and the expected data by equations.

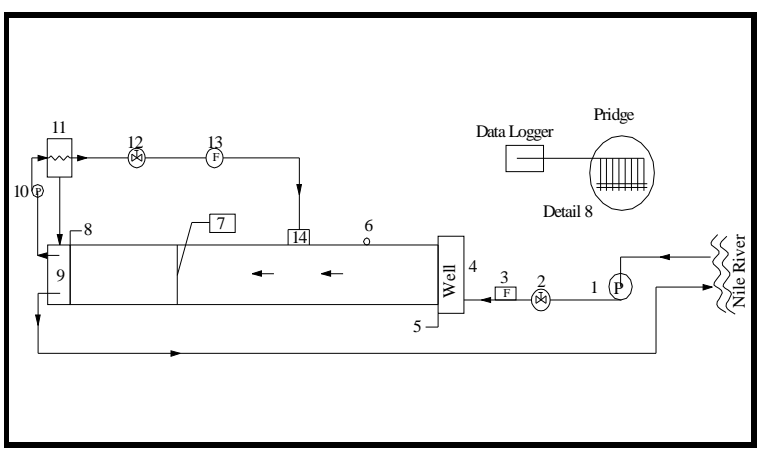

Fig. 3 Feeding process system

$1 \quad$ Centrifugal pump

2 Gate valve

3 Electro magnetic flow meter

$4 \quad$ Well

5 Weir

$6 \quad$ Water level gage

7 Bridge having 25 temp. sensors

8 Water level adjustment gate

9 Well for collecting water.

10 Centrifugal pump.

11 Electric heater.

12 Gate valve.

13 Ultra sonic flow meter

14 Hot discharge sump.

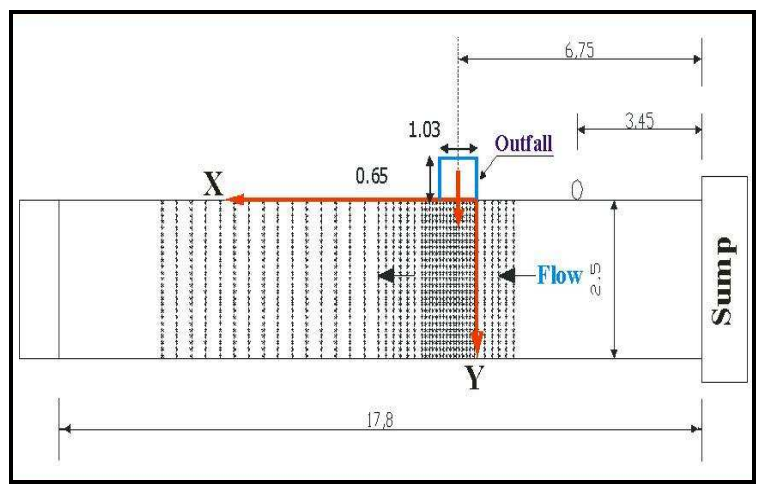

Fig. 4 Sensors location in the flume (Dims in $\mathrm{m}$ )

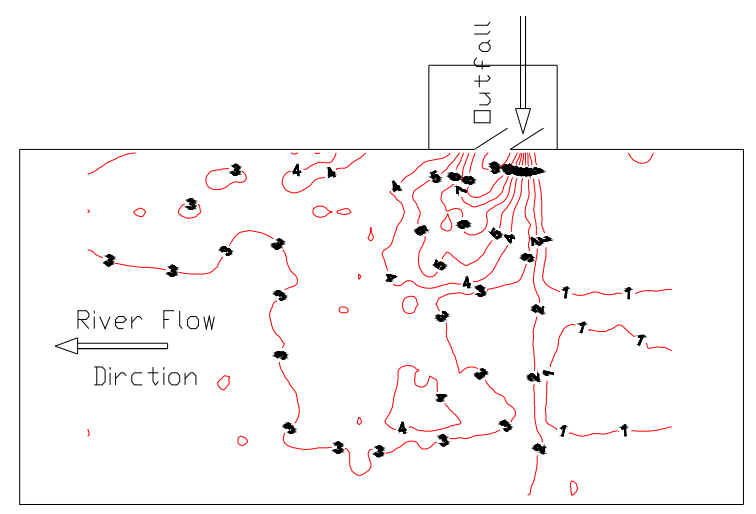

Fig. 5 Temperature contour lines show the thermal plume 


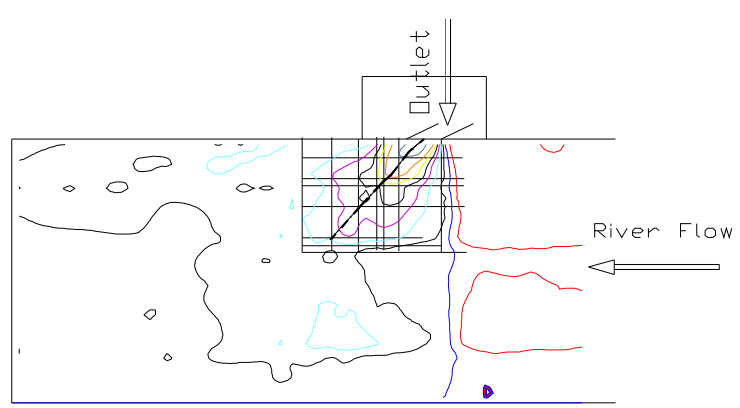

Fig. 6 shows the center line of the thermal plumes

\section{EXPERIMENTAL INVESTIGATION}

\subsection{Test Program}

Based on the real data in Egypt, four values of aspect ratios $(1,1.2,1.4$, and 1.6) were considered, and four values of the cross flow ratio $(0.1,0.2,0.3$, and 0.4$)$ were selected, in this work. Aspect ratio, cross flow ratio, and outlet angle are tested individually in different test runs keeping other factors constant. These arrangements were repeated for three outfall angles $\left(30^{\circ}, 60^{\circ}\right.$, and $\left.90^{\circ}\right)$ as in Fig. 7.

The temperature difference between the ambient and the hot discharge $\Delta \mathrm{T}=10^{\circ} \mathrm{C}$ is taken constant all over the work. Also the ambient water depth is kept $0.3 \mathrm{~m}$. The channel width is $2.5 \mathrm{~m}$.

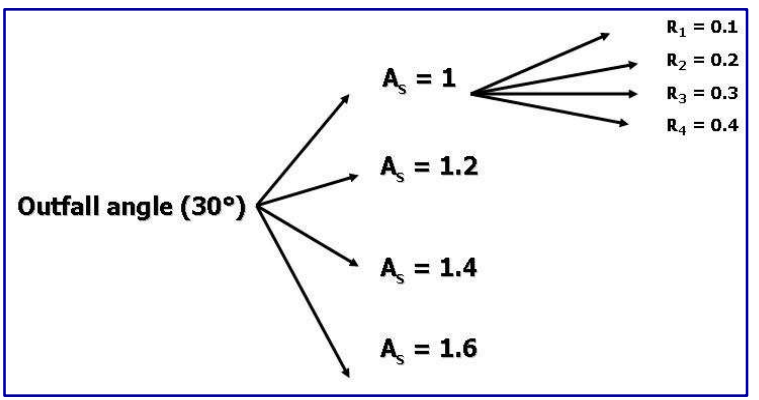

Fig. 7 shows test program at one of outfall orientation

\subsection{Developing Formulae of the Mixing Zone Center-Line Length}

The measured data was analyzed to calculate the mixing zone center-line distance, to have the dimensionless empirical formulae.

The data fit computer program was used to develop the relation between the center-line temperature distance and cross-flow ratio, Froude Number, and aspect ratio. The center line is defined as the center line of the thermal plumes.

Several equations defining the mixing zone center-line temperature distance are available. Among these is the formula of Millar and Brighouse, [3]. This equation determines the center-line temperature distance in deep water. This equation is a function of Froude Number and aspect ratio at outfall angle of $90^{\circ}$ in stagnant water which mean no cross flow ratio. Miller's and Brighouse equation is:

$$
\frac{s}{\sqrt{h_{o} b_{o}}}=\left(1 / 2.659 \frac{\Delta T}{\Delta T_{o}} \mathrm{~A}_{\mathrm{s}}^{0.253} \mathrm{~F}_{0}^{0.052}\right)^{-1.815}
$$

\subsubsection{Developing a formula for the center line} length at outfall angle $90^{\circ}$

In the present study the tests were conducted at outfall angle $90^{\circ}$ to develop a formula having the same parameters Froude Number $\left(\mathrm{F}_{\mathrm{o}}\right)$, aspect ratio $\left(A_{s}\right)$, cross flow ratio $(R)$ and condition of outfall angle $90^{\circ}$ as Miller's equation, [1]. The measured data was analyzed to calculate the mixing zone center-line distance to have the following dimensionless empirical formula:

$\frac{s}{\sqrt{h_{o} b_{o}}}=\left(1-\operatorname{Exp}\left(\frac{\Delta T}{\Delta T_{o}}\right) / \operatorname{Exp}(1)\right) \operatorname{Exp}\left(a R+b A_{s} F_{o}+\left(1-\frac{\Delta T}{\Delta T_{o}}\right) c+d\right)$

Where: $\mathrm{a}=-0.1994, \mathrm{~b}=-0.1688, \mathrm{c}=0.8121$ and $\mathrm{d}=$ 4.694 .

Miller's equation and the present equation were used to calculate the center-line of thermal plumes of the same power station, Stolzenbach and Harleman power station in Michigan [1]. Fig. 8 shows a comparison between the measured and predicted data by Miller's equation and the present developed equation for Stolzenbach power station. It could be noticed that the developed formula fits more the measured data than Miller equation in the range before $\Delta T / \Delta T_{o}=0.35$, after that range Miller's equation fits more than the developed equation. This means that the developed equation gives a good prediction for center-line length for a certain range of temperature difference $\left(\Delta T / \Delta T_{o}>0.35\right)$ which is the range of temperature difference of 4 to $10{ }^{\circ} \mathrm{C}$ for this study.

\section{Sensitive analyses of the cross flow ratio}

Figure 9 shows that the cross flow ratio $(\mathrm{R})$ has an effect on the mixing zone center line. On the other hand, increasing $\mathrm{R}$ in open channels increasing the cooling efficiency and decreasing the mixing zone center line distance. Miller's equation could be applied only in the case of stagnant water and did not consider moving water. In that case, the developed equation with the effect of $\mathrm{R}$ could be applied.

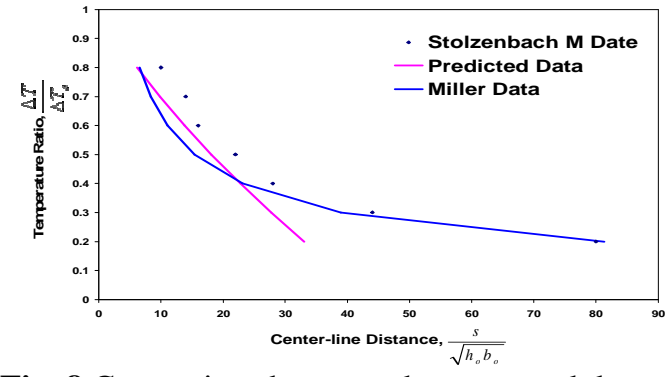

Fig. 8 Comparison between the measured data and predicted by developed and Miller's formulae of Stolzenbach power station 


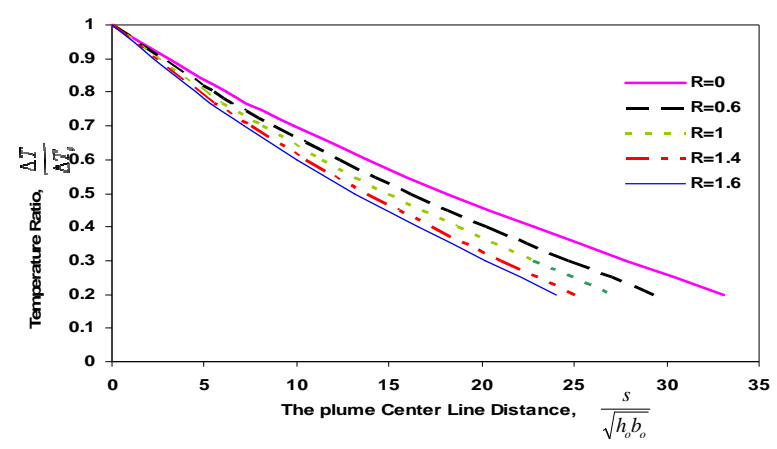

Fig. 9 Effect of the change of cross flow ratio on the thermal plume center line

\subsubsection{Developing formula for the center line length at outfall angles $60^{\circ}$ and $30^{\circ}$}

More tests were conducted at the model with outfall angles $60^{\circ}$ and $30^{\circ}$. The measured data was analyzed to calculate the mixing zone center-line distance, to have the dimensionless empirical formulae for the two outfall angles $\left(30^{\circ}, 60^{\circ}\right)$. The dimensionless formula for $30^{\circ}$-outfall angle is as follows:

$\frac{s}{\sqrt{h_{o} b_{o}}}=\left(1-\operatorname{EXP}\left(\frac{\Delta T}{\Delta T_{o}}\right) / \operatorname{EXP}(1)\right) \operatorname{EXP}\left(a R+\left(A_{s} F_{o}\right)^{b}-c\right)$

Where; $a=2.258, b=0.873$ and $c=-1.26$

While the dimensionless formula for $60^{\circ}$-outfall angle is as follows:

$\frac{s}{\sqrt{h_{o} b_{o}}}=\left(1-\frac{\Delta T}{\Delta T_{o}}\right)^{a}\left(E X P\left(b R+c A_{s}+d F_{o}+e\right)\right)$

Where a, b, c, d, and e are constants equal to 0.856, $1.696,-0.856,-0.103$ and 4.293 respecively.

Equations (4) and (5) are applied within the present ranges of experiments. They have a deviation of about $10.5 \%$ and $12 \%$ respectively. Figs. 10 and 11 show the deviation of center line distance between measured and calculated data for outfall angles $60^{\circ}$ and $30^{\circ}$.

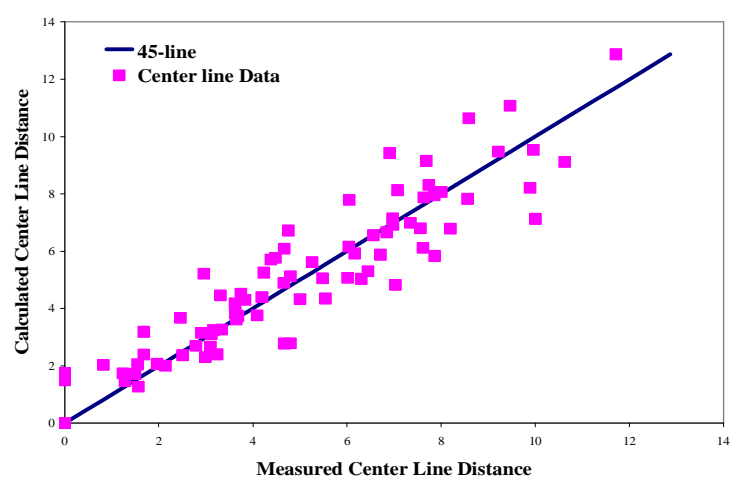

Fig. 10 The deviation between measured and calculated data for outfall angle $60^{\circ}$

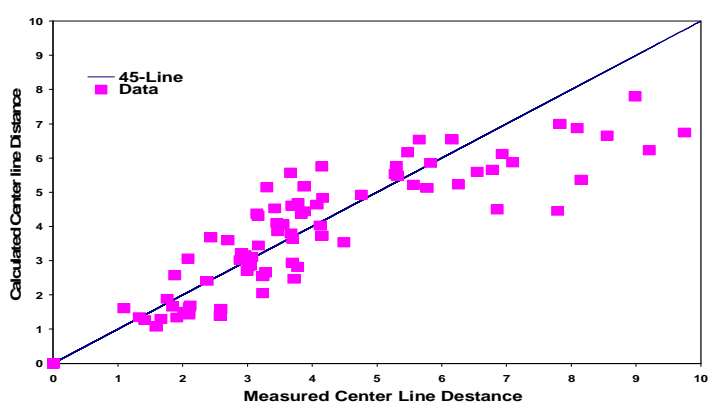

Fig. 11 The deviation between measured and calculated data for outfall angle $30^{\circ}$

Verification of developing formula for the center line length at outfall angles $60^{\circ}$ and $30^{\circ}$

The obtained formulae were verified the data of ElTebeen Power Plant in Egypt with its two modules, as the following:

\begin{tabular}{|c|c|c|c|c|}
\hline Outfall angle & $\Delta_{\mathrm{T}}$ & $\mathrm{R}$ & $\mathrm{A}_{\mathrm{S}}=\mathrm{h}_{\mathrm{o}} / \mathrm{b}_{\mathrm{o}}$ & $\mathrm{F}_{\mathrm{o}}$ \\
\hline $60^{\circ}$ & 9 & 1 & 0.3 & 0.5651 \\
\hline $30^{\circ}$ & 8 & 0.784 & 0.223 & 6.44 \\
\hline
\end{tabular}

Equations (4) and (5) were applied and Figs. 12 and 13 shows the comparison between the predicted center-line temperature distances of the thermal plumes by the present developed formulae and ElTebeen data. It is clear that the results of developed equations are in good agreement with the measured data

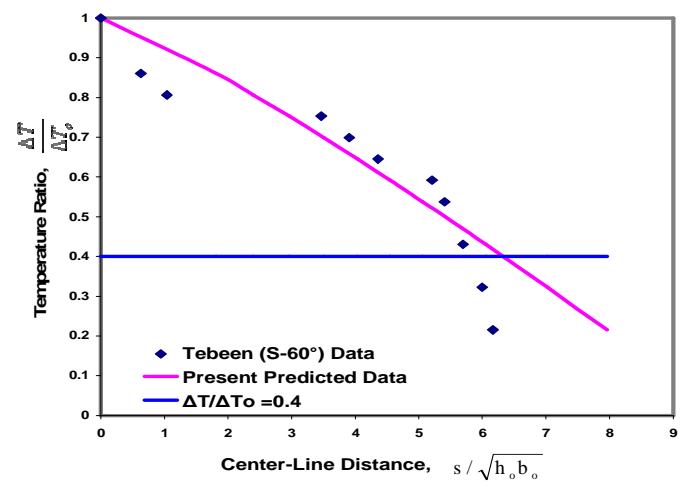

Fig. 12 Results of developed Eq. and El-Tebeen data for $60^{\circ}$ outfall angle 


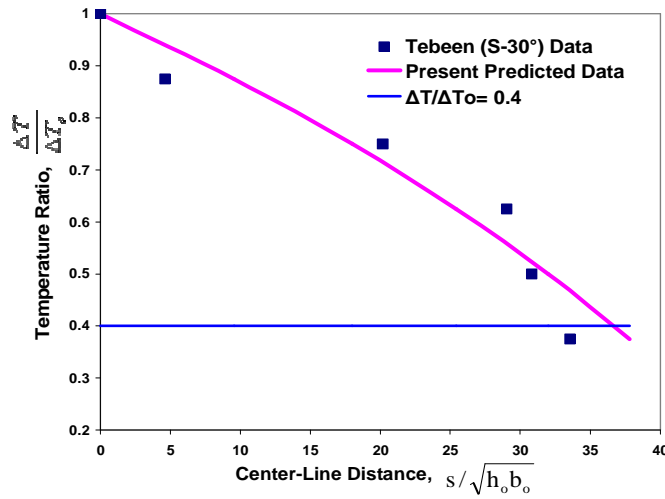

Fig. 13 Results of developed Eq. and El-Tebeen data for $30^{\circ}$ outfall angle

\subsection{Sensitivity of the outfall orientation on the center line length}

A good agreement was observed between the expected center line by the developed formula of $60^{\circ}$ outfall angle and the measured data of El-Tebeen $\left(60^{\circ}\right.$ outfall angle), while the developed equation of $30^{\circ}$ outfall angle have considered deviation as shown in Fig. 14. Fig. 15 shows a Comparison of mixing zone center line calculated by $60^{\circ}$ analytical model and $30^{\circ}$ analytical model against El-Tebeen $\left(30^{\circ}\right.$ outfall) field data. A good agreement was observed between the expected center line by the developed formula of $30^{\circ}$ outfall angle and the measured data of El-Tebeen $\left(30^{\circ}\right.$ outfall angle), while the developed equation of $60^{\circ}$ outfall angle have big deviation. Which mean that the outfall angle has an effect on the mixing zone center line distance.

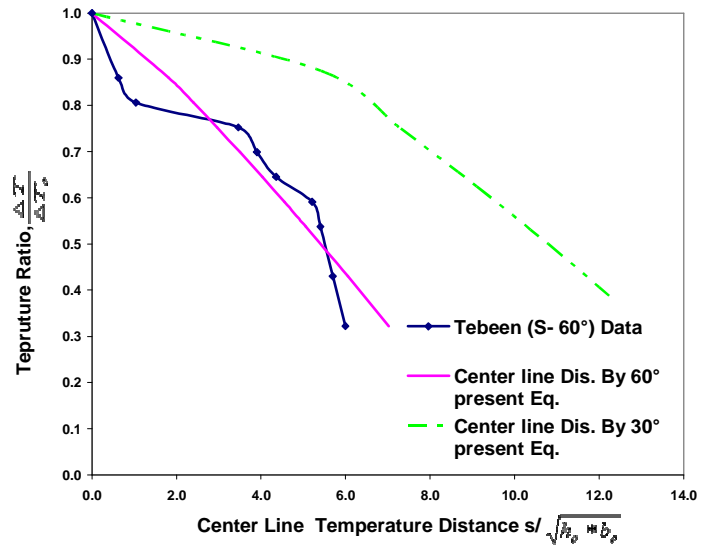

Fig. 14 Comparison between the predicted mixing zone center line temperature distance calculated by $60^{\circ}$ and $30^{\circ}$ analytical model against the measured data of El-Tebeen $30^{\circ}$

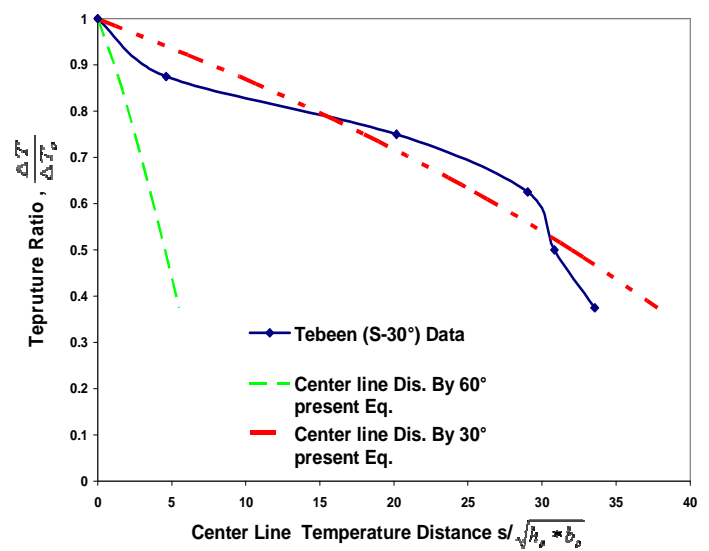

Fig. 15 Comparison between the predicted mixing zone center line temperature distance calculated by $60^{\circ}$ and $30^{\circ}$ analytical model against the measured data of El-Tebeen $60^{\circ}$

\section{CONCLUSIONS}

From the present investigations the following could be concluded:

1) The developed formula for center line length for certain temperature difference could predict the center line length as Miller's equation.

2) The factor (R) improved the results of the developed equation and gave the variety of using it in stagnant and moving water.

3) The outfall angle influences the thermal plume center-line length. This was detected while comparing the predicted data from the developed formulae at $30^{\circ}$ and $60^{\circ}$. Every equation suits its conditions only.

In general it is concluded that the developed equations for mixing zone center-line length, could be a good tool in prediction the thermal plume size. Also these predicted formulae could help in updating the Environment and Water Legislations in Egypt and other countries having the same conditions.

\section{RECOMMENDATIONS}

The following recommendations could be considered in the future work:

1) More studies are to be conducted to determine the relation between Froude number and aspect ratio and cross flow ratio and their influence on the thermal plume size.

2) More studies are needed to be conducted to establish relations that could calculate the dimensions of the mixing zone for wider range of temperature difference ratios. 


\section{REFERENCES}

[1] EL-Wakil, M.M., "Power Plant Technology ", McGraw-Hill Book Company, 1985.

[2] Amer A., "Open Channel" ECIHP, Egyptian Committee of International Hydrological Program, Environmental Hydrology for Arid and Semi-arid Regions, Regional Training Post Graduate Course, 2005.

[3] Miller D. S. and Brighouse B. A., "Thermal Discharge", A guide to power plant and process plant cooling water discharges into rivers, lakes and seas, Publication ISBN 0906085934 British Hydrodynamics Research Association, 1984.

[4] Hydraulics Research Institute, National Water Research Center, "Shoubra El-Khimah Power Plant Hydrological Survey", report No. 13, 1988.

[5] Hydraulics Research Institute, National Water Research Center, "Hydrothermal Model Study of Western Cairo Power Station Extension", report No. 26, 1989.

[6] Hydraulics Research Institute, National Water Research Center, "Extension of Cairo South
Power Plant, Hydraulic Study of the Cooling System", report No. 11, 1992.

[7] Hydraulics Research Institute, National Water Research Center, "El-Kureimat Power Plant Project Hydraulic Model Study", report No. 20, 1993.

[8] Hydraulics Research Institute, National Water Research Center, "Cairo North Power Plant Cooling System Modules I \&II, report No. 8, 2003.

[9] Hydraulics Research Institute, National Water Research Center, "New Nubaria Power Plant Modules I \& II", Report on Model after Modification Progress Report No.3, report No. 57, 2003.

[10] Hydraulics Research Institute, National Water Research Center, "El-Kureimat Power Plant Hydrothermal Model Study, Model Design", report No. 45, 2004.

[11] Hydraulics Research Institute, National Water Research Center, "El-Tebeen Power Plant Hydrothermal Model Study, Model Design, Construction, and Calibration", report No. 93, 2005. 